\title{
Pondering on British science policy
}

\section{A brief report of last week's meeting on the future of British science administration reveals differences of opinion that will not be easily bridged.}

Edinburgh. The British government, headed at the time by Prime Minister Margaret Thatcher, ignored the warnings of its top scientific advisory committee when it decided in 1987 to withdraw its support for 'near market' research. Six years later, the need to remedy the subsequent neglect of applied research has become a central focus for the government as it draws up its promised White Paper (policy document) on the organization of science.

A succession of speakers at a meeting organized in Edinburgh last week by the Edinburgh International Science Festival and Nature urged the government to turn its back on Thatcher's approach and take firmer steps to stimulate the links between industry and the academic world. One of these was Sir Graham Hills, vice-chancellor of the University of Strathclyde until two years ago and now a member of body whose earlier advice was ignored, the Advisory Council on Science and Technology (ACOST).

Referring to the 1987 decision — which had, for example, led to the virtual drying up of research council funds for applied research in universities - Hills said that "the one thing that the UK was poor at was near market research". ACOST had tried to block the government's move; but "it was a battle fought and lost", he said.

Three other needs emerged as key points that speakers at the meeting urged the government to address in the White Paper: an improved career structure for scientists, particularly for postgraduate students employed on short-term contracts; an assurance that any reorganization of the research councils will protect the science base and not become too "technology driven"; and closer coherence between national and European science policy.

Hills defended proposals made by ACOST, in its submission to the government on the White Paper, to separate funding bodies such as research councils from the institutions performing research. Such a separation, he suggested, would sharpen the value judgements made by scientists in seeking funds. Furthermore, a previous concern with the inputs into scientific research had resulted in a relative neglect of managing the outputs, he said; this had impaired the relationship between industry and government as 'customers' of research, and the scientific community as 'providers'.

Hills described ACOST's proposals to reorganize the five current research councils into two new bodies - the Council for the Advancement of Scientific Knowledge and the Council for Mission Oriented Research — as a first attempt to "bring respect" into supporting and managing research linked to the needs of industry by clarifying the purpose of research and distinguishing different funding routes.

But this approach was criticized by David Wallace, professor of physics at the University of Edinburgh, and chairman of the science board of the Science and Engineering Research Council (SERC). Wallace said that separating funding for basic and applied research would have two major defects. First, it implied a single research council covering all fields of basic science; "I do not believe that is practical".

Second, it was based on the false premise that there is a linear development leading from basic research through strategic and applied research to the development of products. But the SERC's experience, which showed areas in which basic research (for example in mathematics) could sometimes have immediate applications, showed that "it does not always work like that", said Wallace. He said industrial collaboration could be dangerous if it led to a particular research project being "technology driven".

There was general agreement at the meeting that a new initiative is needed from the government to provide greater infrastructural support for linking basic and applied research, as the Fraunhofer Institutes do in Germany (and as the proposed Faraday Centres, which now appear to have been abandoned, would have done in Britain). Several participants praised the LINK scheme, run with support from the Department of Trade and Industry, as a step in this direction, despite its excessive bureaucracy.

But there was also a strong feeling that such initiatives should be built on the resources and capabilities of universities. "Contact between applied research and basic research raises the standards of the former and introduces realistic priorities into the latter" said Max Irvine, principal of the University of Aberdeen. "Universities would seem to be an ideal setting for such contacts to flourish."

Irvine said he applauded signs of a greater public commitment to near market research, describing the dominance of the Stock Market as the "major deterrent" to industrial investment in research, since, in contrast to Japan, it demanded too high a return. But resources to provide this commitment should not be taken entirely from within the public sector science vote; funds should be transferred from other government departments if the country's capacity for basic science "is not to be crippled".

A strong plea for better treatment of postgraduate students was made by David Glover, head of the Cancer Research Campaign's cell cycle group at the University of Dundee. "The lack of career structure is evident from research student days onward", said Glover. One problem was the wide disparity in student stipends. He urged the government to follow the example given by medical charities, whose current level of stipends for postgraduate students is about twice that offered by the research councils. $\mathrm{He}$ added that the career structure of scientists in universities and research institutes needed to be carefully re-examined if Britain was to make best use of its limited resources of trained personnel.

Another area needing attention, said Glover, was the interaction between Britain's national research strategy and that originating from the Commission of the European Communities (EC) in Brussels. An increasing proportion of Britain's research resources were being directed to EC projects that had a short life span and were often poorly thought out, he said. "The programmes are highly bureaucratic, and neglect career structure even more than our national programmes."

Further support for closer attention to this area came from Wallace, who questioned the way in which William Waldegrave, the cabinet minister responsible for science, had asked for comments in preparing his White Paper on how British research could best "complement" that conducted through European programmes. "What we should really be seeking is a coincidence of purpose, rather than complementarity", he said.

Speaking from the floor, Joe Lamb, professor of physiology at the University of St Andrews, and chairman of the Save British Science campaign, said that one important problem that needed to be tackled was "a lack of vision" in most sectors of industry. This was despite the fact that, if analysed on a sector-by-sector basis, those companies which had the highest expenditure on research and development - in particular in the chemicals and pharmaceuticals industry -were also the companies that were the most successful in international markets.

The message that left the meeting was that the Thatcher 'mini-revolution' in leaving the stimulation of technology (and thus indirectly of research) to the market-place has failed. New government measures are needed, and hopes are high that Waldegrave is prepared to deliver.

David Dickson 